\title{
Correction to: A transgenerational toxicokinetic model and its use in derivation of Minnesota PFOA water guidance
}

\author{
Helen M. Goeden · Christopher W. Greene - James A. Jacobus
}

Published online: 25 November 2019

(c) The Author(s) 2019. This article is published with open access

\section{Correction to: Journal of Exposure Science \& Environ- mental Epidemiology \\ https://doi.org/10.1038/s41370-018-0110-5}

This paper has been corrected because the model runs used to create the serum curves for the Alternative Scenarios in Fig. 7 contained errors, resulting in an underestimation of serum concentrations. The errors did not affect the model results for the MDH selected RME scenario, which was used to develop Minnesota's water guidance values. The corrected Fig. 7 is presented below along with revised text for the last three sentences of the Results section.

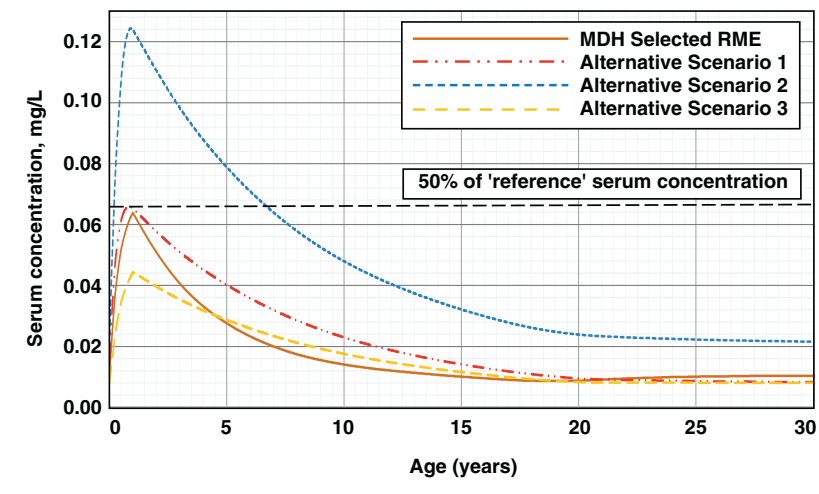

Fig. 7
Model simulations of breastfeeding scenarios that combined different central tendency and upper percentile values for various model parameters were also assessed (see Table 2) using MDH's HBGV of $0.035 \mu \mathrm{g} / \mathrm{L}$.

The peak serum concentrations for the alternative scenarios ranged from 69 to $195 \%$ of the peak serum concentration predicted using the RME scenario selected by MDH (Fig. 7). While these alternative scenarios produce similar or somewhat higher peak serum concentrations, these estimates were used for comparison purposes only to better understand the most sensitive model parameters.

The updates to this Article take effect in both the HTML and PDF versions.

Open Access This article is licensed under a Creative Commons Attribution 4.0 International License, which permits use, sharing, adaptation, distribution and reproduction in any medium or format, as long as you give appropriate credit to the original author(s) and the source, provide a link to the Creative Commons license, and indicate if changes were made. The images or other third party material in this article are included in the article's Creative Commons license, unless indicated otherwise in a credit line to the material. If material is not included in the article's Creative Commons license and your intended use is not permitted by statutory regulation or exceeds the permitted use, you will need to obtain permission directly from the copyright holder. To view a copy of this license, visit http://creativecommons. org/licenses/by/4.0/. 